\title{
PROJECT OF UPDATING THE CONCEPTUAL FRAMEWORK OF THE IAS/IFRS AND ITS INFLUENCE ON THE ACCOUNTING IN THE CZECH REPUBLIC ${ }^{1}$
}

\author{
Olga Malíková, Zdeněk Brabec
}

\section{Klíčová slova:}

finanční účetnictví, koncepční rámec, konvergence, tvưrci standardů, účetní výkaznictví, účetní výkazy

\section{Key words:}

financial accounting, conceptual framework, convergence, standard setters, financial reporting, financial statements

\begin{abstract}
Abstrakt
Článek se zabývá komparativní analýzou současného koncepčního rámce IASB s návrhem nového vylepšeného znění, které je tvořeno $\mathrm{v}$ rámci společného konvergenčního projektu Rady pro mezinárodní účetní standardy (IASB) a amerického výboru pro vydávání účetních standardů (FASB). Následně jsou analyzovány některé z toho vyplývající důsledky pro účetnictví v České republice.
\end{abstract}

\begin{abstract}
This article is engaged in a comparative analysis of the existing IASB's framework with the proposal of a new improved version, which is elaborated within the common convergence project of the International Financial Reporting Standards (IASB) and the United States Financial Accounting Standards Board (FASB). After that some inferential conclusions for accounting in the Czech Republic are analysed.
\end{abstract}

\section{Introduction}

At the present time, when the globalization of economy is growing and capital markets are more connected than ever before, the information that is presented in the financial statements of the listed companies is becoming more important. The capital providers need to know, how the managers of the company govern the resources that they invested and if the use of these resources is as efficient as it could be. This effectiveness could be expressed through the rating of the company. ${ }^{2}$

Because the investors could place their capital into companies from different countries, it is necessary to ensure the comparability of information contained in financial statements of these companies. The best way to reach the international comparability of financial statements is to use the same basis for preparing of financial statements worldwide. The harmonisation of

\footnotetext{
${ }^{1}$ This article is worked up within the research project „Kritické komentáře $\mathrm{k}$ vybrané problematice teorie účetnictví a její aplikaci v podmínkách současné účetní regulace (Critical comments to chosen problems of accounting theory and its application under the conditions of contemporary accounting regulation)“", which is realised with support of the specific research on the Faculty of Economics at the Technical University of Liberec, in year 2010.

${ }^{2}$ UŽIK,M., ŠOLTÉS V., Vplyv zmeny ratingu na ceny spoločností obchodovaných na kapitálovom trhu.
} 
the bases that are used for preparing financial statements through the world would also afford advantages for multinationals, which prepare their consolidated financial statements because this process would be much easier as well as less expensive. Such an appropriated basis could be represented by a single set of understandable and enforceable global accounting standards such as for example International Financial Reporting Standards (IAS/IFRS) ${ }^{3}$ or United States Generally Accepted Accounting Principles (US GAAP). These two above mentioned standards are nowadays being converged to each other and both standard setters, US Financial Accounting Standards Board (FASB) and International Accounting Standards Board (IASB), cooperate jointly on creating new standards or on improving the existing ones.

This article would like to focus on the updating common conceptual framework because this topic is currently being updated and this is not so much examined in the Czech Republic nowadays. Firstly the convergence of IFRS and US GAAP as a starting point for creation of the new conceptual framework is mentioned. After that the conceptual framework is shortly described in general and then the proposal of the new converged conceptual framework and the existing IASB's framework are compared. At the end some consequences of the conceptual framework for the accounting legislation in the Czech Republic are highlighted.

\section{Goals and methods}

According to the wide range of problems that could be discussed within the area of conceptual framework this article is engaged in highlighting the main differences between the proposal of the four phases of the new conceptual framework project and the existing IASB's framework. Firstly a description of the convergence process and the importance of the conceptual framework in general is made, followed by the comparative analysis of the main differences between the existing IASB's framework and the new converged conceptual framework. The last part provides a synthesis of the main consequences of the conceptual framework for the accounting in the Czech Republic.

\section{Convergence between IFRSs and US GAAP}

The existence of the single set of understandable and enforceable global accounting standards is a very important presumption for ensuring the comparability of the financial statements of the companies that are placed in different countries. So in 2002 the two main standard setters (IASB and FASB) decided to remove the differences between their existing standards as soon as it is practicable and to cooperate jointly on creating of the new ones to ensure that once achieved compatibility will be maintained in the future. This decision was declared in September 2002 in the Memorandum of Understanding, which is also known as the Norwalk Agreement.

The cooperation was further strengthened in February 2006 when a roadmap for convergence between IFRSs and US GAAP for the period 2006 - 2008 was established. This document distinguishes two main phases of the convergence process. Short-term convergence, which should have been finished until 2008, contained 10 topics that represented major differences, which should have been removed. Other 11 topics were selected for other joint projects on which both boards were working. In 2008, both boards issued an update to the Memorandum

\footnotetext{
${ }^{3}$ The abbreviation IAS/IFRS is used because the standards published before the year 2002 were entitled as International accounting standards (IAS).
} 
of Understanding, which revised a progress of the topics that were established in a roadmap for convergence.

One of these joint projects is engaged in the development of an improved common conceptual framework that should provide a sound foundation for developing future accounting standards. Such a conceptual framework represents a necessary presumption for reaching the main target of the convergence program, which is the creating of accounting standards that are principles-based, internally consistent and internationally converged. ${ }^{4}$

\section{Importance of the conceptual framework}

The conceptual framework establishes the concepts that are essential for true and fair view of financial reporting. More detailed it defines the purpose of financial reporting, provides a description of fundamental qualitative characteristics, basic elements of financial statements, constraints and underlying assumptions and principles, which are needed to prepare and present financial statements faithfully. The information embodied in the framework is important for a broad range of its users such as national or international standard setters, preparers as well as users of financial statements, auditors etc.

Warfield, Weygandt and Kieso ${ }^{5}$ describe the concepts that are embodied in the conceptual framework as the process, which ends through the accomplishment of the objective of financial reporting. In the third level, there are the essential assumptions, principles and constraints that have an influence on qualitative characteristics of accounting information and elements of financial statements, which are contained in the second level. The first level is represented by the objective of financial reporting that describes the purpose of the information that is presented in financial statements.

The conceptual framework itself is not a real standard and so it does not define any solutions of particular situation that are originated from business transactions. The importance of conceptual framework depends on the approach that is used by a standard setting process. So there exist some differences between US GAAP and IFRS ${ }^{6}$ in this area because US GAAP set more detailed rules and IFRS applies principles-based approach by standard-setting. It is hard to say which approach is better because both of them have both strengths and weaknesses. ${ }^{7}$ For example in existing IASB's framework there is nothing that should override any specific standard IAS/IFRS but if there does not exist any specific standard that solves any particular problem so the conceptual framework should be used as a guidance in that situation.

\section{Development of the new conceptual framework - comparison of the existing IASB's framework and the proposal of the new one}

The two main standard setters in the world (IASB and FASB) decided to improve their existing conceptual frameworks by refining, updating, completing, and converging them into

\footnotetext{
${ }^{4}$ IASB. Conceptual framework.

${ }^{5}$ WARFIELD, T. D, WEYGANDT, J. J, KIESO, D. E. Intermediate Accounting: Principles and Analysis, s. 30.

${ }^{6}$ A short summary of the differences of existing conceptual frameworks of IASB and US GAAP is available in BULLEN, H.G., CROOK, K. Revisiting the Concepts.

${ }^{7}$ A little discussion to this topic can be found in NOBES, C.; PARKER, R Comparative international accounting, s. 108-109.
} 
a common conceptual framework according to the results of the completed phases of this project. Both Boards can use this new common framework in developing new and revised accounting standards. The existing frameworks are more that 20 years old and so it is necessary to create such a conceptual framework that will represent the possibly best conversion of the existing ones as well as it will solve current problems, which occur in financial reporting. It was further decided to create firstly concepts that are applicable to business entities in the private sector and after that the possibility will be judged to use those concepts for financial reporting by other types of entities, such as not-for-profit entities in the private sector and, in some jurisdictions, business entities in the public sector.

This project was divided into eight phases, which should have been stepwise finished according to the project plan $^{8}$ that was discussed by the Boards in February 2005. The progress in development of the new conceptual framework does not continue as quickly as it was supposed and so only first four phases are active currently. The phases of the project are as follows: ${ }^{9}$

- A Objective and qualitative characteristics.

- B Elements and recognition.

- C Measurement.

- D Reporting entity.

- E Boundaries of financial reporting and Presentation and Disclosure.

- F Purpose and status of the framework.

- $\mathrm{G}$ Application of the framework to not-for-profit entities.

- $\mathrm{H}$ Remaining issues, if any.

The phases A and D are almost finished, so final chapters of these phases should be published in the second half of 2010. The other two active phases are nowadays being discussed and the Discussion Papers are planned to be published in the year 2011.

\subsection{Objective of financial reporting and qualitative characteristics}

The objective of financial reporting constitutes the foundation of the conceptual framework, which is further conducted by other aspects of the framework that should be helpful to accomplish the purpose of financial reporting, which means to provide information that is decision-useful to capital providers or to other users of financial reporting. To achieve the objective it is important to present financial statements in accordance to the qualitative characteristics of accounting information that distinguish more useful information from inferior information for decision-making purposes.

According to the existing IASB's framework financial statements should "...provide information about the financial position, performance and changes in financial position of an entity that is useful to a wide range of users in making economic decisions." definition of the objective, seven groups of users of financial statements and their information needs are named in this document. As qualitative characteristics of financial statements

\footnotetext{
${ }^{8}$ This proposed project plan is available for example in DELOITTE. Conceptual Framework - Overall Approach to the Project.

${ }^{9}$ IASB. Conceptual framework.

${ }^{10}$ IASB. Framework for the Preparation and Presentation of Financial Statements, paragraph 12.
} 
understandability, relevance, reliability and comparability are assigned followed by the definition of timeliness and balance between benefit and cost that are two constraints on relevant and reliable information. This framework further makes two underlying assumptions, which require preparing of the financial statements on the accrual basis and according to the going concern.

During phase A of the conceptual framework project the definitions of the objective of financial accounting, qualitative characteristics of financial reporting information and tradeoffs among qualitative characteristics should be considered. The first chapter of exposure draft of this phase defines the objective of general purpose financial reporting ${ }^{11}$ as a provision of "...financial information about the reporting entity that is useful to present and potential equity investors, lenders, and other creditors in making decisions in their capacity as capital providers." 12 So the primary user group is in comparison with the existing IASB's framework narrowed to only capital providers but it does not mean that this information could not be useful for other users of financial reporting. It just declares that the information needs of capital providers are paramount in deciding on the principles for recognition, measurement, presentation and disclosure. This user group was chosen because is has "...the most direct and immediate interest in an entity's ability to generate net cash inflows and management's ability to protect and enhance capital providers' investments." 13

The most important information that is provided by financial reporting includes information about the economic resources of the entity, which means assets, and the claims to those resources that are composed of liabilities and equity. Also useful is information about the effectiveness of the entity's transactions, other events and circumstances that could involve economic resources and claims of the entity. The information about the entity's financial performance during the period that is measured by accrual accounting as well as by cash flows is important too. Last but not least useful are management's explanations and other information that can help to understand users the information, which is given in the financial statements. Such information is needed for assessing net cash inflows of the entity and it helps by evaluating of management and its stewardship responsibilities.

The second chapter of exposure draft of phase A describes qualitative characteristics as the key attributes which make financial information useful. The summary of the qualitative characteristics could be presented for example in the form of following picture.

\footnotetext{
${ }^{11}$ The term general purpose financial reporting means reporting that should satisfy the information needs of a wide range of users and especially those users who don't have the ability to get all the needed financial information from an entity and therefore must rely, at least partly, on the information provided in financial reports.

${ }_{12}$ IASB. Exposure draft of an improved Conceptual Framework for Financial Reporting: Chapter 1: The Objective of Financial Reporting, Chapter 2: Qualitative Characteristics and Constraints of Decision-useful Financial Reporting Information, OB 2.

${ }^{13}$ IASB. Exposure draft of an improved Conceptual Framework for Financial Reporting: Chapter 1: The Objective of Financial Reporting, Chapter 2: Qualitative Characteristics and Constraints of Decision-useful Financial Reporting Information, BC 1.19.
} 


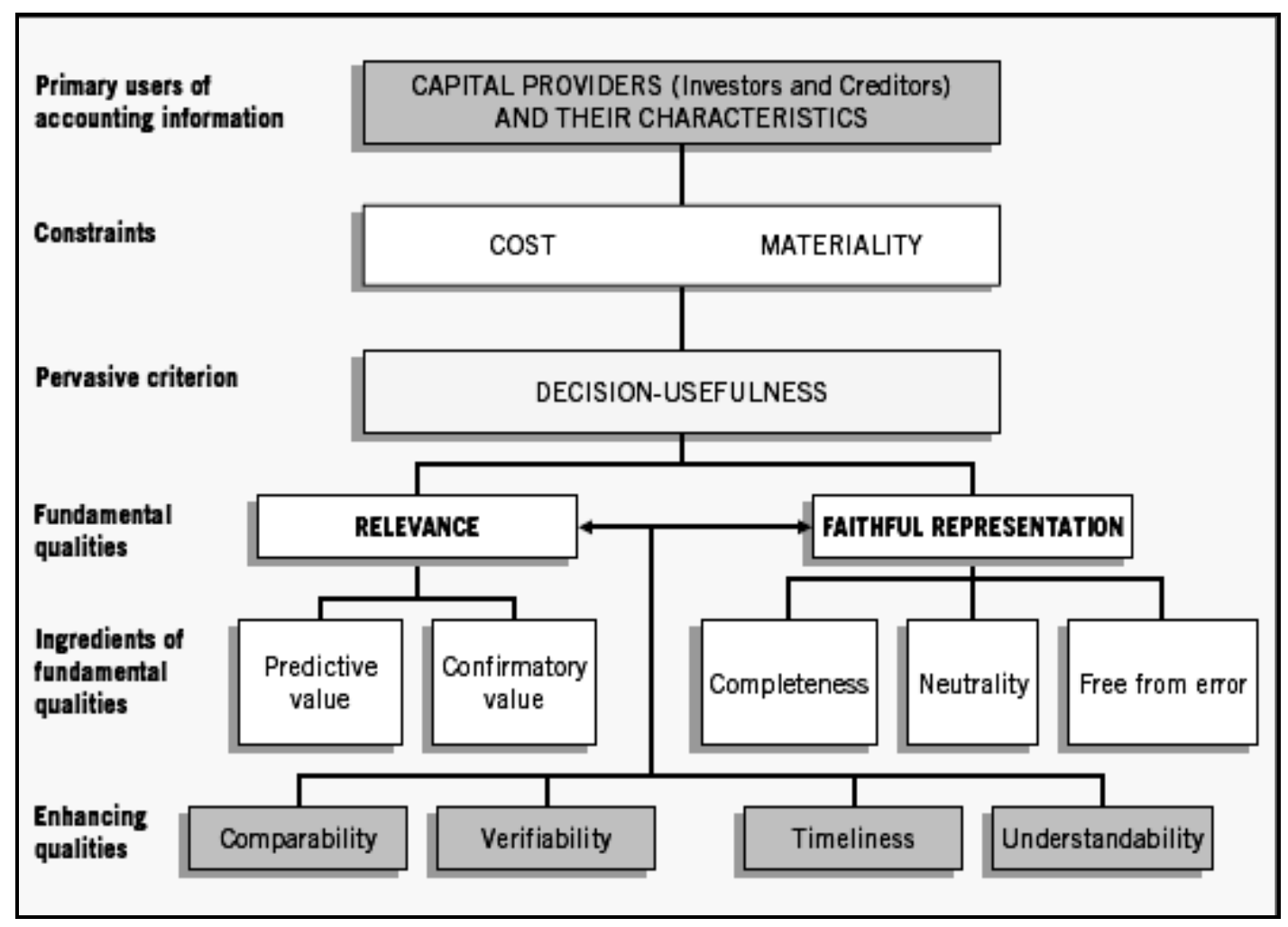

Figure No. 1: Relationship between qualitative characteristics

Source: KIESO, D. E., WEYGANDT, J. J., WARFIELD, T. D. Intermediate Accounting: IFRS Edition. Volume 1. $1^{\text {st }}$ ed. New Jersey: John Wiley \& Sons, 2010. s. 44. ISBN 978-0470-61630-7.

The qualitative characteristics can be distinguished into fundamental and enhancing characteristics, which depend on their influence on the usefulness of financial reporting information. The two fundamental qualitative characteristics are essential for decisionusefulness of financial information. The information is relevant if it has predictive or confirmatory value or both, which means that it can influence the decisions of capital providers. Faithful representation should ensure that decision-useful financial information represents faithfully the economic phenomenon that it purports to represent, which is achieved when the depiction of an economic phenomenon is complete, neutral, and free from material error. This characteristic replaced the term reliability that is used in the existing IASB's framework because the interpretation of this term was not accurate and in addition, the term faithful representation embodies substance over form condition as a component of its own.

The four enhancing qualitative characteristics - comparability, verifiability, timeliness and understandability - help to distinguish information more useful from less useful as much as possible. Comparability should enable users to identify the real similarities and differences in economic events between companies or it can compare similar information about the same entity from period to period. Verifiability helps to assure users that the information represents faithfully the economic phenomena that it purports to represent, which means that knowledgeable and independent observers could reach general consensus because independent measures and same methods are used in financial reporting. Timeliness should ensure that decision-makers obtain the needed information before it loses its capacity to 
influence their decisions. Understandability helps the users who have a reasonable knowledge of business, economic and financial activities and financial reporting, and who analyze the information with reasonable diligence to comprehend the meaning of information given by financial reporting.

When using the qualitative characteristics the two overriding factors that limit the information provided by financial reporting have to be taken into account. These factors are materiality and cost. The information is material if its omission or misstatement has an influence on users' decisions, which are made on the basis of an entity's financial information. Materiality depends on the nature and amount of the item judged in the particular circumstances. The cost constraint means that the benefits of providing information have to be compared with the costs of collecting, processing, verifying and disseminating of this information.

\subsection{Definitions of elements, recognition and derecognition}

Elements of financial statements constitute the building blocks with which financial statements are constructed. The existing IASB 's framework defines five terms that are assets, liabilities, equity, revenues and expenses, which are connected with providing information related with the financial position and performance. The first three terms relate to the balance sheet and the other ones describe the building blocks of income statement. ${ }^{14}$ To incorporate the given item into the financial statement or income statement this element has to be recognised, which means that this item meets the definition of an element and satisfies the criteria for recognition as well. These criteria are probability of the future economic benefit associated with the item, which will flow either to or from the entity, and the item has a cost or value that can be measured with reliability. ${ }^{15}$

In the existing conceptual frameworks, there are some difficulties in their definitions because some terms are not described completely, such as for example the probability of the cash flow that is associated with the item or the term control that is used it in the same sense as that one used for purposes of consolidation accounting. Other group of problems could not be solved according to the existing framework because they did not exist at the publication date. So it can happen that some assets or liabilities do not meet the existing definition. Another problem is connected with capital maintenance because IASB's framework allows a choice between physical and financial capital maintenance, whereas FASB's framework adopts financial capital maintenance and rejects physical capital maintenance. Lastly, there is no definition of the term derecognition, that is the removal of the item from the financial statements, although there exists some standards that describe such situations. ${ }^{16}$

Phase B should refine and converge the existing Board's frameworks in three following areas. Firstly the definitions of asset and liability should be revised and clarified, then the differences in definitions of other elements are planned to be resolved and lastly the recognition criteria should be revised so that they provide a basis for resolving issues such as derecognition and unit of account.

\footnotetext{
${ }^{14}$ After the amendment of IAS 1 in 2007, which shall be applied for annual periods beginning either on or after 1 January 2009, the term balance sheet was replaced by statement of financial position and income statement was renamed to statement of comprehensive income.

${ }^{15}$ This second criterion for recognition is described in chapter 3.3.

${ }^{16}$ For example IAS 39, Financial Instruments: Recognition and Measurement.
} 
On the present there was only a little progress done in this phase so the following working definitions of asset and liability ${ }^{17}$ were adopted tentatively:

"An asset of an entity is a present economic resource to which the entity has a right or other access that others do not have."

"A liability of an entity is a present economic obligation for which the entity is the obligor."

Both these definitions are accompanying by the explanation of three key terms, which are at the asset definition present, economic resource and right or other access that others do not have and in case of labiality definition present, economic obligation and obligor. The above mentioned definitions will be examined according to the results of a number or the Boards' joint projects, such as for example Revenue Recognition and Financial Instruments with Characteristics of Equity project or the IASB Derecognition of Financial Instruments project.

\subsection{Measurement}

The measurement concepts are closely connected with the recognition of the elements of financial statements because for example according to the existing IASB's framework the element should be recognised, if the item has a cost or value that can be measured with reliability. The measurement is in the existing IASB's framework defined as "...the process of determining the monetary amounts at which the elements of the financial statements are to be recognised and carried in the balance sheet and income statement." ${ }^{18}$ In this conceptual framework four measurement bases are named - historical cost, current cost, realisable (settlement) value and present value that are extended by fair value basis in some standards ${ }^{19}$. Contemporarily, the historical cost is mostly used for its advantage, which reposes upon its ability to represent faithfully the amount that was paid for an asset or that had to be paid for a liability. This measurement basis has nevertheless a strong disadvantage because the historical cost does not deal with the effects of changing value of non-monetary assets. That is why other methods are used instead of it, as for example, fair value that represents the amount for which an asset could be exchanged, a liability settled, or an equity instrument granted, between knowledgeable, willing parties in an arm's length transaction

During phase $\mathrm{C}$ of the conceptual framework project guidance should be provided for selecting measurement bases that satisfy the objective and qualitative characteristics of financial reporting. In 2006 the Boards defined three following milestones:

- Milestone I: Defining and describing the properties of potential measurement bases.

- Milestone II: Evaluating measurement bases using criteria that include the qualitative characteristics.

- Milestone III: Conceptual conclusions and practical applications from Milestones I and II.

In the first milestone the list of nine measurement bases candidates was published, which were: past entry price, past exit price, modified past amount, current entry price, current exit price, current equilibrium price, value in use, future entry price, and future exit price.

\footnotetext{
${ }^{17}$ These definitions were published in October 2008 after the joint meeting of IASB and FASB and are available in FASB. Joint Meeting - IASB and FASB.

${ }^{18}$ IASB. Framework for the Preparation and Presentation of Financial Statements.

${ }^{19}$ For example IAS 16, IAS 38, IAS 39, IAS 41 etc.
} 
These candidates, along with their variations were classified according to time frame and they were so selected that they are appropriate for both assets and liabilities and so two definitions for each candidate were given - one from the perspective of an asset and one from the perspective of a liability ${ }^{20}$. Some of these bases are currently used in practice, and some are newly proposed (for example, current equilibrium price). The above mentioned basis should be discussed further and not suitable candidates should be eliminated in the next milestones.

Further the factors were discussed that the Boards should consider when making future standards-level decisions about measurement methods. Five these factors were developed that might be considered in selecting from among alternative measurement bases and their relation to the objective of financial reporting and the qualitative characteristics of decision-useful information was discussed. The following five factors should represent an appropriate starting point for developing a Discussion Paper. Among these factors pertain: ${ }^{21}$

- method of value realization,

- cost of preparing and using measures,

- relative level of confidence in different measures,

- use of consistent measures for similar items and items used together,

- separability of changes in measures.

In July 2010, the Boards reached tentative decisions ${ }^{22}$ in four areas that are relating to the further development of preliminary views for this chapter of the conceptual framework. Firstly the implications of the objective of financial reporting for measurement were discussed. It was stated that all of the financial statements provide information that is useful to their users and so the objective is reached when the effect of a particular measurement selection on all of the financial statements is considered. Secondly it was pointed out that the influence of fundamental qualitative characteristics (relevance and faithful representation) on selecting measurement basis will be discussed later. Thirdly the terms historical cost and fair value should not be further used in the measurement chapter because they don't describe clearly and accurately the set of possible measurement methods, which are in this phase considered. As the last thing the moment was discussed when the measurement chapter should be accomplished. It will be done at that time when specific measurements for particular assets and liabilities are prescribed and when examples or cases exist that demonstrate how the measurement chapter's concepts might be applied.

\subsection{Reporting entity concept}

Complete and clear definition of the term reporting entity is prerequisite presumption for right selection of that sorts of entities, which should (or should not) issue financial statements and it helps to decide as well, if and what other entities should be included in consolidated financial statements. For that reason the definition of reporting entity, which is embodied in the existing IASB's conceptual framework, seems to be insufficient because the reporting entity is defined only in one sentence without any further explanation.

\footnotetext{
${ }^{20}$ The Definitions of Measurement Basis Candidates are available in FASB. Conceptual Framework Project Phase C: Measurement Milestone I Summary Report-Inventory and Definitions of Possible Measurement Bases.

${ }^{21}$ IASB. Conceptual Framework-Measurement.

${ }^{22}$ At the same place.
} 
Thus the goal of phase D is a clear and complete description of what a reporting entity is, a definition of the purpose of consolidated and combined financial statements and a decision whether control is the right basis for consolidation. These problems are solved in the exposure draft that was published in May 2010. Reporting entity, which should be designed to be consistent with the objective of financial reporting, is described as "... a circumscribed area of economic activities whose financial information has the potential to be useful to existing and potential equity investors, lenders, and other creditors who cannot directly obtain the information they need in making decisions about providing resources to the entity and in assessing whether management and the governing board of that entity have made efficient and effective use of the resources provided." 23 This definition is followed by three features that clarify in more details the key features of economic activities and that are necessary but not always sufficient to identify a reporting entity.

In most cases, legal entities are classified as reporting entities with the exception if the economic activities of two legal entities cannot be objectively distinguished or if any part of business activities can be objectively separated from the rest of entity activities.

Further the situation is defined when an entity controls another entity as a situation, when the entity "...has the power to direct the activities ${ }^{24}$ of that other entity to generate benefits for (or limit losses to) itself." ${ }^{25}$ This is necessary for deciding, which entities will prepare consolidated financial statements that are most likely to provide useful information to more users. Then the description of parent-only financial statements and combined financial statements follows, which could contain additional information that is not embodied in consolidated financial statements and so it may be useful for the users.

\section{Consequences for the accounting in the Czech Republic}

The proposed changes of the conceptual framework will definitely have an influence on the accounting in the Czech Republic. However, how strong this influence will be in fact depends, for first on the amount of Czech companies that are bound now or will be bound in the future to prepare their financial statements according to the IAS/IFRS. In this sense it has to be mentioned that the Czech Republic as a member state of the European Union has to implement Accounting directives of the $\mathrm{EU}^{26}$. After the implementing of the EU directives into the Czech accounting law ${ }^{27}$ the companies, who are listed in the EU member states, shall prepare their separate or consolidated ${ }^{28}$ financial statements according to the IAS/IFRS. Nowadays the use of the IAS/IFRS is discussed for other types of companies ${ }^{29}$ in the EU, which are not listed presently. For second the member states of EU have the opportunity to

\footnotetext{
${ }^{23}$ IASB: Exposure draft: Conceptual Framework for Financial Reporting: The Reporting Entity, RE2

${ }^{24}$ The phrase power to direct seems to be a conceptually more robust basis for determining the composition of a group reporting entity than the notion of risks and rewards.

${ }^{25}$ IASB: Exposure draft: Conceptual Framework for Financial Reporting: The Reporting Entity., RE 7

26 The use of the IAS/IFRS in the EU is regulated especially through the Regulation (EC) No. 1606/2002 of the

European Parliament and of the Council of 19. July 2002 on the application of International accounting standards that is applicable after 1. January 2005 and for some companies after 1. January 2007.

${ }^{27}$ Especially $\$ 19$ and $§ 23$ a of the Zákon č. 563/1991 Sb., o účetnictví.

${ }^{28}$ It means that the company prepares financial statements because it is listed itself or it is for example a subsidiary of the parent company that shall it report to.

${ }^{29}$ The European Commission is currently discussed the possibility of application of IFRS for Small and Medium-sized Entities within the EU.
} 
allow the use of IAS/IFRS for other types of companies as well or they can implement more principles and methods used in the IAS/IFRS to their domestic law.

Therefore, the factual impact of the development of the conceptual framework depends on that if the firms in the Czech Republic prepare their financial statements according to the IAS/IFRS or if they should possibly prepare them in the future. That is why the listed companies or their units should give their attention to these changes because the new common conceptual framework will form foundation for their financial reporting. The others have not any obligation to study the conceptual framework or its changes yet but with regard to the above mentioned possible enlargement of usage of the IAS/IFRS within the EU the firms and their accountants should focus on this topic. Especially for those firms the study of the conceptual framework and its improvements could afford another look on accounting because in the Czech accounting regulations there is no such comprehensive document that will contain all main goals, presumptions and definitions that are needed for preparing financial statements, which represent faithfully economic phenomena. In the Czech accounting regulations there are only few requirements, mostly in form of list of explicit items without any economical justifying of their content. Another difference ${ }^{30}$ between Czech national regulation of accounting and IAS/IFRS flows from the definition of the main goal of financial accounting that is embodied in the Czech accounting regulations and the objective of accounting according to the IAS/IFRS. In the Czech Republic the main goal of accounting is to "...provide true and fair view of the object of accounting and financial situation of the entity" ${ }^{31}$ but there are many requirements which cause that financial accounting underlies the taxation. IAS/IFRS demands that the financial reporting should afford financial information that is useful for capital providers and their ability to make economic decisions. Therefore, there are no requirements that will describe the accounting methods, which should be used to determine the income tax obligation.

\section{Conclusion}

The purpose of this article was to focus on the comparison of the new converged conceptual framework with the existing IASB's conceptual framework and to highlight some inferential conclusions for the accounting in the Czech Republic. As the project of the new conceptual framework is realised as one of the convergence projects, the convergence between IAS/IFRS and US GAAP was mentioned at first followed by the short description of the purpose of conceptual framework in general. As the third part of this article the first four phases of the proposed conceptual framework with the existing IASB's framework were compared. Lastly the conclusions for different types of companies were outlined because the proposed conceptual framework will have different impact on various types of firms that are active in the Czech Republic.

It will be interesting if and eventually how the proposals embodied in the first four phases of the new converged conceptual framework will be changed until the individual phases are published as final chapters. Secondly other four currently inactive phases will definitely contain important information for all interested groups that are concerned with financial reporting. And from the point of view of companies in the Czech Republic it will be very

\footnotetext{
${ }^{30}$ For more information about this problem could be recommended MLÁDEK, R. Koncepční rámec IFRS a US GAAP where the author summarises the key differences between Czech accounting legislation and IFRS and US GAAP with the intention of conceptual framework.

${ }^{31}$ Translation of the Zákon č. 563/1991 Sb., o účetnictví, §7.
} 
important which types of companies will have to or will be allowed to prepare their financial statements according to the IAS/IFRS. On the other hand, regarding to the existing huge differences between the Czech legislation and IAS/IFRS it would be useful to adopt the converged conceptual framework into our national rules.

\section{Literature:}

[1] BULLEN, H.G.; CROOK, K. Revisiting the Concepts. [online] Norwalk: FASB, c2005. [cit. 2010-09-02] Available from WWW: <http://www.fasb.org/news/SDR_10_20-

21_08.pdf>http://www.fasb.org/project/communications_paper.pdf

[2] DELOITTE. Conceptual Framework - Overall Approach to the Project. [online] Deloitte, c2010 [cit. 2010-09-02] Available from WWW:

<http://www.iasplus.com/agenda/framework.htm>

[3] FASB. Conceptual Framework Project Phase C: Measurement Milestone I Summary Report-Inventory and Definitions of Possible Measurement Bases. [online] Norwalk: FASB, c2007. [cit. 2010-09-02] Available from WWW: $<\mathrm{http}$ ///www.fasb.org/project/CF_Milestone_I_Summary_Report.pdf>

[4] FASB. Joint Meeting - IASB and FASB. [online] Norwalk: FASB, c2007. [cit. 2010-0902] Available from WWW: <http://www.fasb.org/news/SDR_10_20-21_08.pdf>

[5] IASB. Conceptual framework. [online] London: IASCF, c2010. [cit. 2010-09-02] Available from WWW:

$<$ http://www.ifrs.org/Current+Projects/IASB+Projects/Conceptual+Framework/Concept ual+Framework.htm>

[6] IASB. Conceptual Framework - Measurement. [online] London: IASCF, c2010. [cit. 2010-09-02] Available from WWW:

$<$ http://www.ifrs.org/Current+Projects/IASB+Projects/Conceptual+Framework/Concept ual+Framework.htm>

[7] IASB. Exposure draft: Conceptual Framework for Financial Reporting: The Reporting Entity. [online] London: IASCF, 2010. [cit. 2010-09-02] Available from WWW: < http://www.ifrs.org/NR/rdonlyres/363A9F3B-D41C-41E7-9715-

79715E815BB1/0/EDConceptualFrameworkMar10.pdf >

[8] IASB. Exposure draft of an improved Conceptual Framework for Financial Reporting: Chapter 1: The Objective of Financial Reporting, Chapter 2: Qualitative Characteristics and Constraints of Decision-useful Financial Reporting Information. [online] London: IASCF, 2008. [cit. 2010-09-02] Available from WWW: <http://www.ifrs.org/NR/rdonlyres/464C50D6-00FD-4BE7-A6FF1BEAD353CD97/0/conceptual_framework_exposure_draft.pdf>

[9] IASB. Framework for the Preparation and Presentation of Financial Statements. [online] London: IASCF, c1989. [cit. 2010-09-02] Available from WWW: $<$ http://eifrs.iasb.org/eifrs/bnstandards/en/framework.pdf>

[10] KIESO, D. E.; WEYGANDT; J. J., WARFIELD, T. D. Intermediate Accounting: IFRS Edition. Volume 1. 1st edition. New Jersey: John Wiley \& Sons, 2010. 800 s. ISBN: 978-0-470-61630-7

[11] MLÁDEK, R. Koncepční rámec IFRS a US GAAP. Účetnictví, roč. 2009, č. 8, s. 60-63. ISSN 0139-5661

[12] NOBES, C.; PARKER, R. Comparative international accounting. 9th edition. Harlow: Prentice Hall, 2006, 576 s. ISBN: 978-0-273-70357-0

[13] UŽIK,M., ŠOLTÉS V., Vplyv zmeny ratingu na ceny spoločností obchodovaných na kapitálovom trhu. E+M Ekonomie a Management. 2009, roč. 12, č. 1, s. 49-56. ISSN 1212-3609 
[14] WARFIELD, T. D; WEYGANDT, J. J and KIESO, D. E. Intermediate Accounting: Principles and Analysis, 2nd edition. New Jersey: John Wiley \& Sons, 2008. $1136 \mathrm{~s}$ ISBN: 978-0-471-73793-3

[15] Zákon č. 563/1991 Sb., o účetnictví. In Sbírka zákonů České republiky. 2008, Available as well from WWW: <

http://www.mfcr.cz/cps/rde/xchg/mfcr/xsl/dane_ucetni_reforma_v_oblasti_vf_pravpred _42073.html >

\section{JEL classification: M41, M48}

\section{Ing. Olga Malíková, Ph.D.}

Odborný asistent Katedra financí a účetnictví

Ekonomická fakulta

Technická univerzita v Liberci

Studentská 2

46117 Liberec 1

olga.malikova@tul.cz

\section{Ing. Zdeněk Brabec}

Doktorand Katedra financí a účetnictví

Ekonomická fakulta

Technická univerzita v Liberci

Studentská 2

46117 Liberec 1

zdenek.brabec@tul.cz 